\title{
Novel approaches for determination of antiretroviral reverse transcriptase inhibitor agent in commercial dosage forms by using spectrofluorimetric, first derivative spectrophotometric, and HPLC methods
}

\author{
Gizem Tiris ${ }^{1,2^{*}}$ (D) Emine Çiloğlu ${ }^{1}$ and Nevin Erk ${ }^{*^{*}}$
}

\begin{abstract}
Background: Rapid, simple, and sensitive spectrofluorimetric, first derivative spectrophotometric, and highperformance liquid chromatographic (HPLC) methods have been developed and validated for determination of tenofovir in pharmaceutical preparations. Spectrofluorimetric method is based on measuring the native fluorescence intensity of tenofovir at $375.0 \mathrm{~nm}$ after excitation at $275.0 \mathrm{~nm}$. Calibration graphics were plotted and were found linear over $4.72-15.75 \mu \mathrm{g} / \mathrm{mL}$ concentration range $\left(r^{2}=0.9994\right)$. The second method developed was the first derivative spectrophotometric method for the analysis of tenofovir performed by measuring the amplitude at 251.7 and $272.6 \mathrm{~nm}$. Linearity was observed in the concentration range $10.0-28.0 \mu \mathrm{g} / \mathrm{mL}\left(r^{2}=0.9998\right)$. On the other hand, HPLC with a diode array detector (DAD). Ritonavir was used as internal standard (IS). HPLC analysis was carried out on a $C_{18}$ column (Wakosil-II $5 \mathrm{C}_{18}$ AR, $4.6 \times 250 \mathrm{~mm}$ ) using a mobile phase consisting of acetonitrile: $0.5 \%$ formic acid $(99.5: 0.5 ; \mathrm{v} / \mathrm{v})$ at a flow rate of $1.0 \mathrm{~mL} / \mathrm{min}$. Injection volume was $5.0 \mu \mathrm{L}$. DAD signals at $260.0 \mathrm{~nm}$ were used. HPLC method was found to be linear over the concentration range of $10.0-100.0 \mu \mathrm{g} / \mathrm{mL}\left(r^{2}=0.9990\right)$.
\end{abstract}

Result: Intra- and inter-day analysis and recovery studies were carried out to investigate precision and accuracy of the proposed spectrofluorimetric, first derivative spectrophotometry and HPLC methods.

Conclusion: We successfully applied the developed methods for determination of tenofovir in tablet formulation. Finally, the proposed methods were compared statistically.

Keywords: Tenofovir, Spectrofluorimetry, HPLC, First derivative spectrophotometry, Quantitative analysis

\section{Background}

Tenofovir disoproxil fumarate (TDF) is a pro-drug of tenofovir which is a phosphorylated adenosine analogue [1]. Tenofovir disoproxil fumarate is an antiretroviral reverse transcriptase inhibitor [2]. Chemical structure of tenofovir disoproxil fumarate is shown in Fig. 1.

\footnotetext{
*Correspondence: gizem.tiris@gmail.com; erknev94@gmail.com

'Department of Analytical Chemistry, Faculty of Pharmacy, Ankara University, Tandoğan, Ankara, Turkey

Full list of author information is available at the end of the article
}

Several methods have been published for the determination of tenofovir in bulk or pharmaceutical formulations and in biological fluids and materials. In the literature, tenofovir has been determined as the only active ingredient and in combination with other active ingredients. These methods include HPLC [3-8], HPLCMS [9], HPLC-MS/MS [10, 11], LC-MS [12-14], LCMS/MS [15-18], UPLC [19-25], UPLC-MS and UPLCMS/MS [22-25], TLC [26], HPTLC [27-29], and spectrophotometric [7, 30-34] methods. 


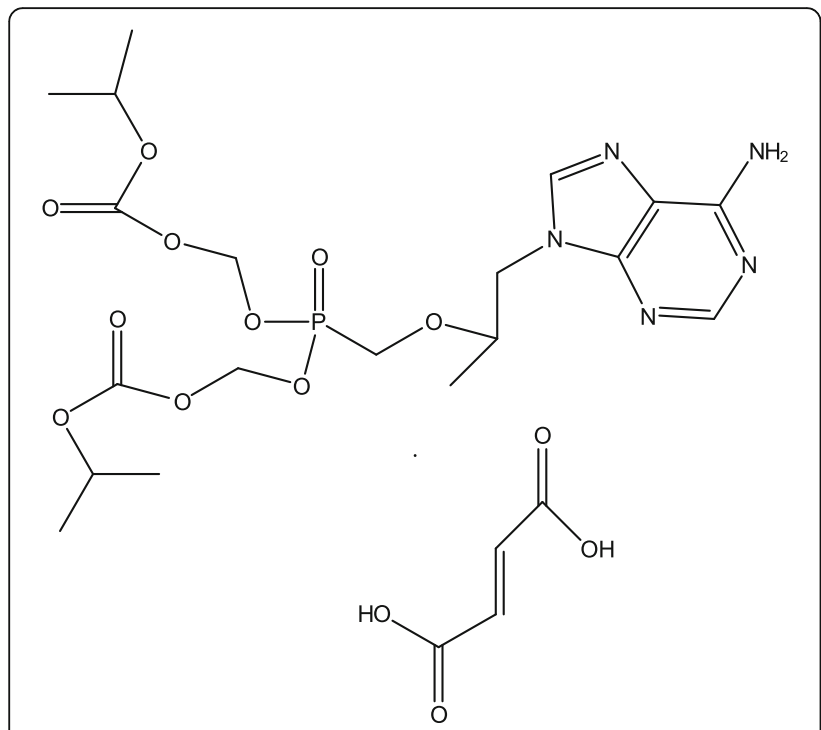

Fig. 1 Tenofovir disoproxil fumarate

This paper describes new, simple, sensitive, and rapid spectrofluorimetric method for the determination of tenofovir in pharmaceutical dosage form. To the best of our knowledge, no spectrofluorimetric method was proposed for the quantitative determination of tenofovir in pharmaceutical preparations. A new HPLC method was also validated for the analysis of tenofovir in pharmaceutical dosage form, and this HPLC method was used as the reference method, and we compared the results obtained from the proposed methods statistically.

\section{Methods}

\section{Apparatus}

An Agilent Technologies Cary Eclipse Fluorescence Spectrophotometer equipped with Agilent Technologies $10.0 \mathrm{~mm}$ quartz fluorescence cells was used for the spectrofluorimetric method. Absorbance measurements were measured on a double beam UV-VIS spectrophotometer model UV-1800 PC by using quartz cells with 10.0-mm path length. For the HPLC analysis, an Agilent 1100 Series HPLC with DAD detector was used.

\section{Software}

Agilent Cary Eclipse ${ }^{\mathrm{TM}}$, UV-Probe 2.52 software, and Agilent ChemStation ${ }^{\mathrm{TM}}$ products were used for spectrofluorimetric, spectrophotometric methods, and HPLC, respectively. Origin $\operatorname{Pro} 8^{\mathrm{TM}}$ software was used for plotting the calibration spectrums and chromatograms shown in this paper.

\section{Reagents and materials}

Acetonitrile and boric acid were purchased from Riedelde Haën', Germany, and methanol was purchased from LiChrosolv $^{\oplus}$, Germany. Dimethylformamide, diethylamine, phosphoric acid, acetic acid, formic acid, sodium hydroxide, sodium dodecyl sulphate (SDS), tween ${ }^{\circ} 80$, cetrimonium bromide (CTAB), tenofovir, caffeine, hydrochlorothiazide, zanamivir, oseltamivir, lopinavir, and ritonavir were all purchased from Sigma-Aldrich ${ }^{\circ}$, USA.

\section{Pharmaceutical compounds and dosage forms}

TDF and its dosage form "Ternavir" $245.0 \mathrm{mg}$ film coated tablet" was kindly provided by ATABAY Pharmaceuticals and Fine Chemicals (Turkey). Tablet formulation contains $300.0 \mathrm{mg}$ TDF which is equal to $245.0 \mathrm{mg}$ tenofovir disoproxil per tablet. Ritonavir which was used as the internal standard in HPLC analysis was kindly provided by AbbVie Medical Drugs Industry and Trade Ltd. Co. (Turkey).

\section{Preparation of standard solutions}

$16.0 \mathrm{mg}$ TDF was weighed and transferred to $50.0-\mathrm{mL}$ volumetric flask and dissolved with distilled water and completed to the volume with the distilled water for the spectrofluorimetric and spectrophotometric methods. Surfactant stock solutions were prepared with distilled water to contain $2.0 \%, \mathrm{v} / \mathrm{v}$ for Tween ${ }^{\circ} 80$, and $2.0 \%, \mathrm{w} / \mathrm{v}$ for SDS and CTAB.

For the HPLC method, $22.5 \mathrm{mg}$ TDF standard was transferred to a $10.0-\mathrm{mL}$ volumetric flask and completed to the volume with methanol. $33.6 \mathrm{mg}$ ritonavir standard was transferred to a $25.0-\mathrm{mL}$ volumetric flask, dissolved and completed to the volume with methanol. Further dilutions from these two stock solutions were made with methanol. All solutions were filtered through $0.45-\mu \mathrm{m}$ filter before injection to the HPLC system.

\section{Preparation of pharmaceutical dosage form}

Ten tablets were weighted accurately and finely powdered and mixed. Powder amount that is equal to the average tablet weight was transferred to a $500.0-\mathrm{mL}$ volumetric flask. Some distilled water was added, and the solution was sonicated for about $10.0 \mathrm{~min}$ for the spectrofluorimetric and spectrophotometric methods. Then, completed to the volume with the same solvent and mixed on a magnetic mixer for about $45.0 \mathrm{~min}$. Further dilutions were made with water.

Powder amount that is equal to average tablet weight was transferred to a $250.0-\mathrm{mL}$ volumetric flask; some methanol was added and sonicated for about $10.0 \mathrm{~min}$ and then completed with methanol to the volume for HPLC analysis. This solution was mixed on a magnetic mixer for about $30.0 \mathrm{~min}$. Further dilutions were made with methanol.

All tablet solutions were filtered through $0.45-\mu \mathrm{m}$ filter before analysis for both methods. 


\section{General analytical procedures}

Spectrofluorimetric measurements were recorded at emission mode after excitation at $275.0 \mathrm{~nm}$. Detector voltage was set at 660.0 volts. Excitation and emission slit widths were $10.0 \mathrm{~nm}$. Native fluorescence intensities at $375.0 \mathrm{~nm}$ were used for the calculations.

HPLC analysis was carried out through Wakosil-II 5 $\mathrm{C}_{18} \mathrm{AR}, 4.6 \times 250 \mathrm{~mm}$ analytical column. Acetonitrile $0.5 \%$ formic acid (99.5: $0.5 ; \mathrm{v} / \mathrm{v}$ ) was used as mobile phase at a flow rate of $1.0 \mathrm{~mL} / \mathrm{min}$. Injection volume was $5.0 \mu \mathrm{L}$. DAD detector was set at 250.0, 254.0, 260.0, 265.0 , and $270.0 \mathrm{~nm}$. Chromatograms obtained at 260.0 $\mathrm{nm}$ were used for the analysis.

The developed analytical method was validated according to international guidelines with respect to certain parameters such as accuracy, precision, and linearity [35].

\section{Results}

\section{Optimization of the spectrofluorimetric method} Effect of the diluting solvent

Firstly, the effect of the diluting solvent on the native fluorescence intensity was investigated. Distilled water, methanol $(\mathrm{MeOH})$, acetonitrile $(\mathrm{ACN})$, and dimethylformamide (DMF) was used as the diluting solvent. Sample concentration was $14.86 \mu \mathrm{g} / \mathrm{mL}$ in each different solution. Spectrums of the sample and blank solutions were recorded. Results obtained are shown in Fig. 2. Distilled water was chosen as the diluting solvent because of the higher native fluorescence intensity obtained.

\section{Effect of $p H$}

After choosing the diluting solvent, effect of $\mathrm{pH}$ on the fluorescence intensity was investigated. A stock solution of Britton-Rabinson solution was prepared. Buffer solutions at different $\mathrm{pH}$ values $(\mathrm{pH} 2.26-10.11)$ were prepared from this solution by using $5.0 \mathrm{~N} \mathrm{NaOH}$ solution. Appropriate volumes of the stock TDF solution were transferred to $10-\mathrm{mL}$ volumetric flasks and completed to the volume with the buffer solutions prepared. Final tenofovir concentration was $14.86 \mu \mathrm{g} / \mathrm{mL}$. Spectrums of the blank and sample solutions were recorded. Native fluorescence intensities of each sample solution with different $\mathrm{pH}$ values are shown in Fig. 3.

As it is seen on the graph, the highest native fluorescence intensity was obtained with the $\mathrm{pH} 2.26$ buffer solution; that is why this $\mathrm{pH}$ was chosen for the spectrofluorimetric analysis.

\section{Effect of volume of the buffer solution}

After choosing the $\mathrm{pH}$ value, effect of the buffer volume used in the sample preparation process was investigated. Dilutions were made from the TDF stock solution to $10.0-\mathrm{mL}$ volumetric flasks to end up with a $14.86 \mu \mathrm{g} / \mathrm{mL}$ tenofovir concentration. Different volumes of the $\mathrm{pH}$ 2.26 buffer solution were added to the flasks and completed to the volume with distilled water or buffer. Native fluorescence intensities were measured, and the results are shown in Fig. 4.

As it is seen in Fig. 4, pH 2.26 buffer solution volume does not affect the native fluorescence intensity significantly. That is why $\mathrm{pH} 2.26$ volume added to the sample solutions was decided to be $1.0 \mathrm{~mL}$ to minimize the use of buffer solution.

\section{Effect of surfactant}

The effect of the surfactant was also investigated. Three different kind of surfactants were chosen: Tween ${ }^{\circ} 80$

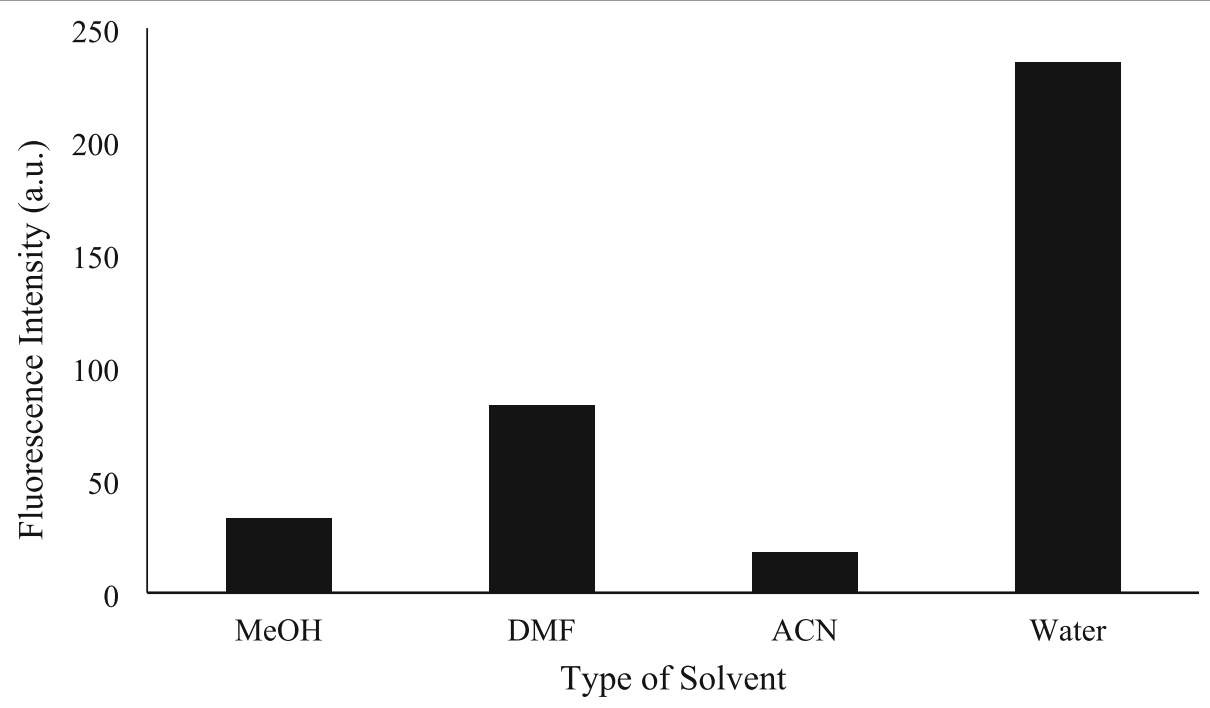

Fig. 2 Effect of diluting solvent on native fluorescence intensity 


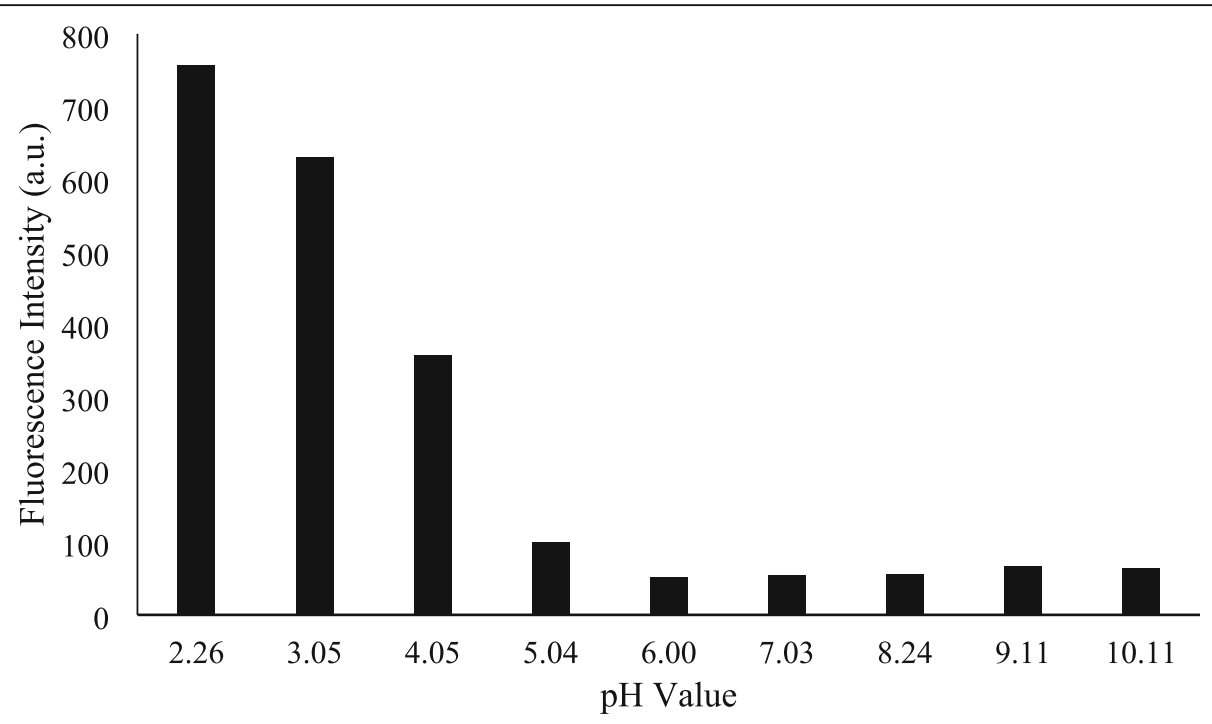

Fig. 3 Effect of pH on native fluorescence intensity

(non-ionic), SDS (anionic), and CTAB (cationic). Solutions were prepared at the rate of $2.0 \% \mathrm{v} / \mathrm{v}$ Tween $^{\oplus} 80$, w/v SDS, and w/v CTAB. One milliliter stock TDF solution, $1.0 \mathrm{~mL}$ pH 2.26 buffer solution, and $1.0 \mathrm{~mL}$ surfactant $\left(0.5 \mathrm{~mL}\right.$ for Tween $\left.{ }^{\odot} 80\right)$ solution were transferred to $10.0-\mathrm{mL}$ volumetric flasks and completed to the volume with water. Results that are obtained are shown in Fig. 5.

Using SDS as the surfactant was found to be the best choice since it provides the highest native fluorescence intensity.

\section{Effect of volume of the surfactant}

Different volumes of the SDS $(2.0 \%, \mathrm{w} / \mathrm{v})$ solution were used to prepare sample solutions. In each solution, 1.0 $\mathrm{mL} \mathrm{pH} 2.26$ buffer solution was also added and the final tenofovir concentration was $14.86 \mu \mathrm{g} / \mathrm{mL}$.
As shown in Fig. 6, there is no significant difference between fluorescence intensities of solutions which were prepared with different volumes of SDS solution. Therefore, SDS solution volume to be added to sample solutions was decided to be $1.0 \mathrm{~mL}$ for the analysis.

\section{Effect of temperature}

The effect of temperature on the native fluorescence intensity was also investigated. Working solutions using $1.0 \mathrm{~mL}$ pH 2.26 buffer and $1.0 \mathrm{~mL} 2.0 \%$ SDS (w/v) solutions and appropriate volume of TDF stock solution and distilled water were prepared. Solutions prepared were kept for $10.0 \mathrm{~min}$ in a thermostatically controlled water bath which was set at different temperatures. Native fluorescence intensities of these solutions are shown in Fig. 7.

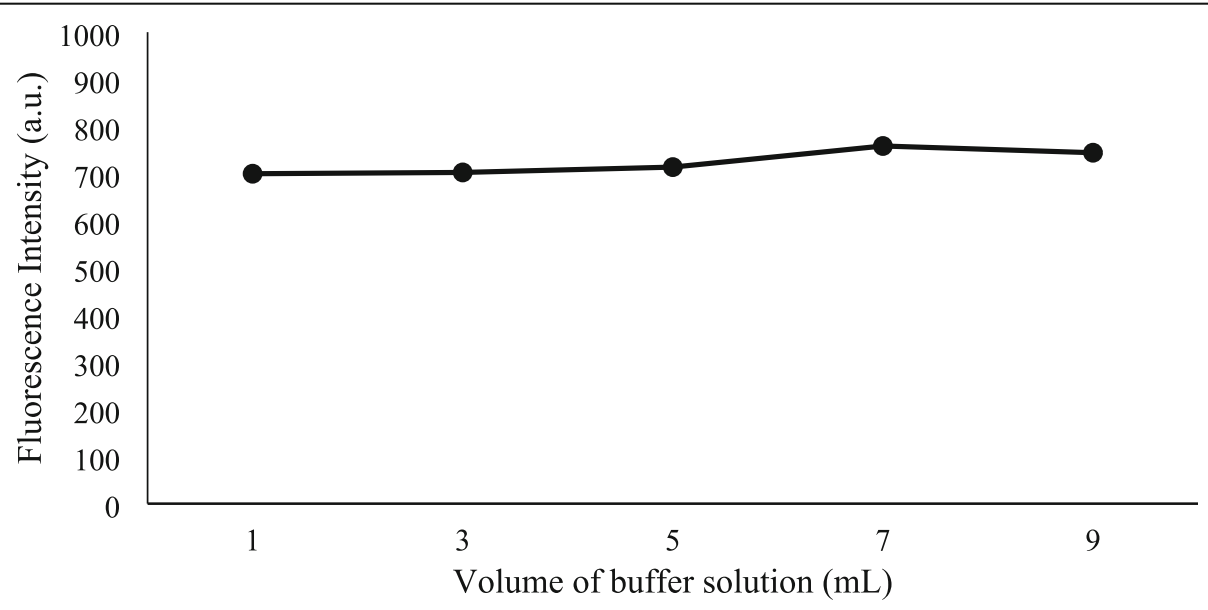

Fig. 4 Effect of the buffer solution volume on native fluorescence intensity 


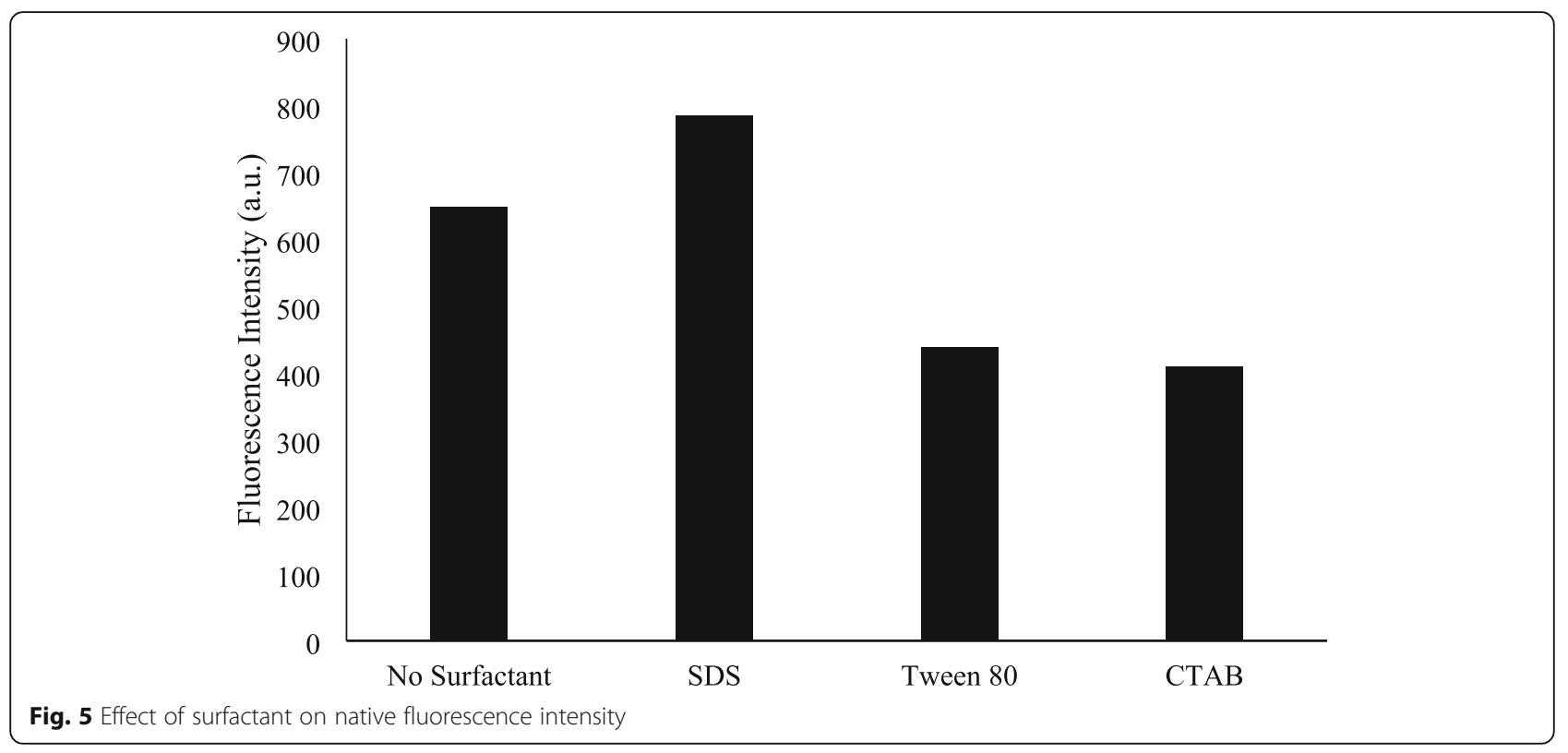

There is a decrease in native fluorescence intensity as the temperature increases. Especially after $50.0^{\circ} \mathrm{C}$, this decrease is much more significant. Therefore, it was decided to perform the analysis at room temperature.

\section{Optimization of the first derivative spectrophotometric} method

The direct UV spectrum and the first derivative spectrum of tenofovir in methanol solutions are shown in Figs. 8 and 9, respectively. Derivative spectra of different orders were studied for tenofovir, and experimental results showed that the first derivative spectra gave well-defined peaks around at ${ }^{1} \mathrm{D}_{251.0}$, and ${ }^{1} \mathrm{D}_{272.0}$, with suitable precision.

\section{Optimization of the HPLC method}

Different column and mobile phase systems and different internal standards were used to achieve the best resolution between tenofovir and the internal standard and to gain the best peak shape and performance

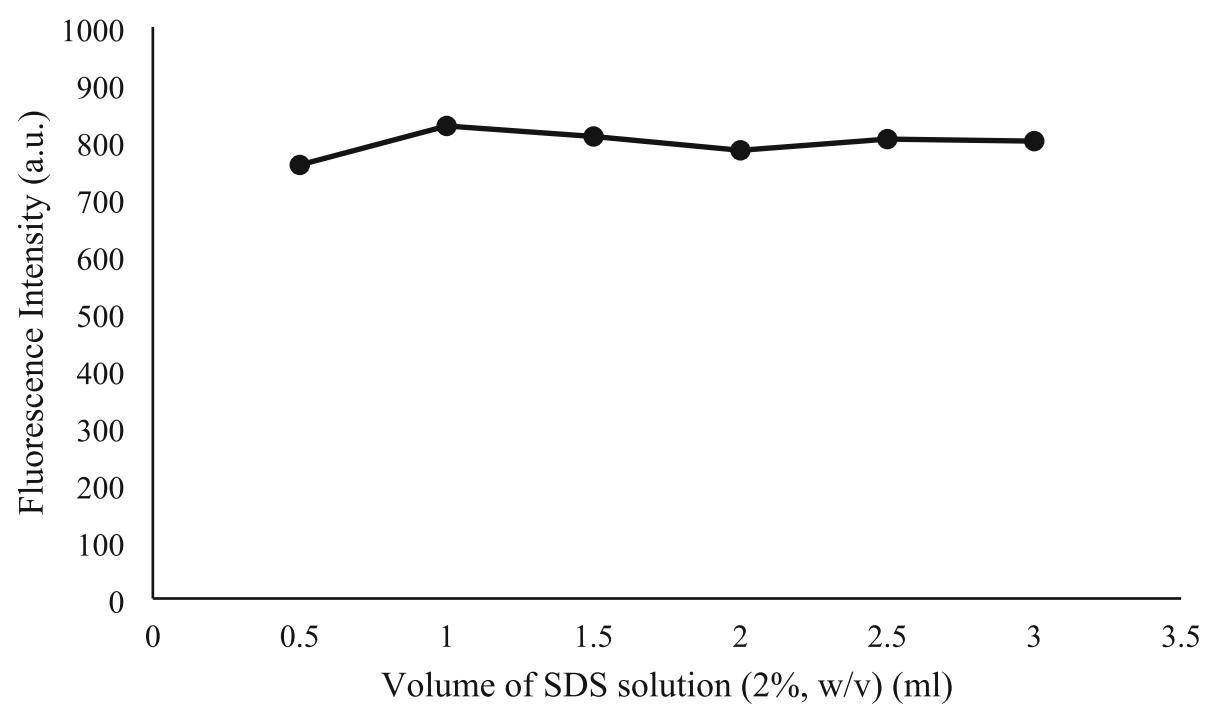

Fig. 6 Effect of SDS solution volume on native fluorescence intensity 


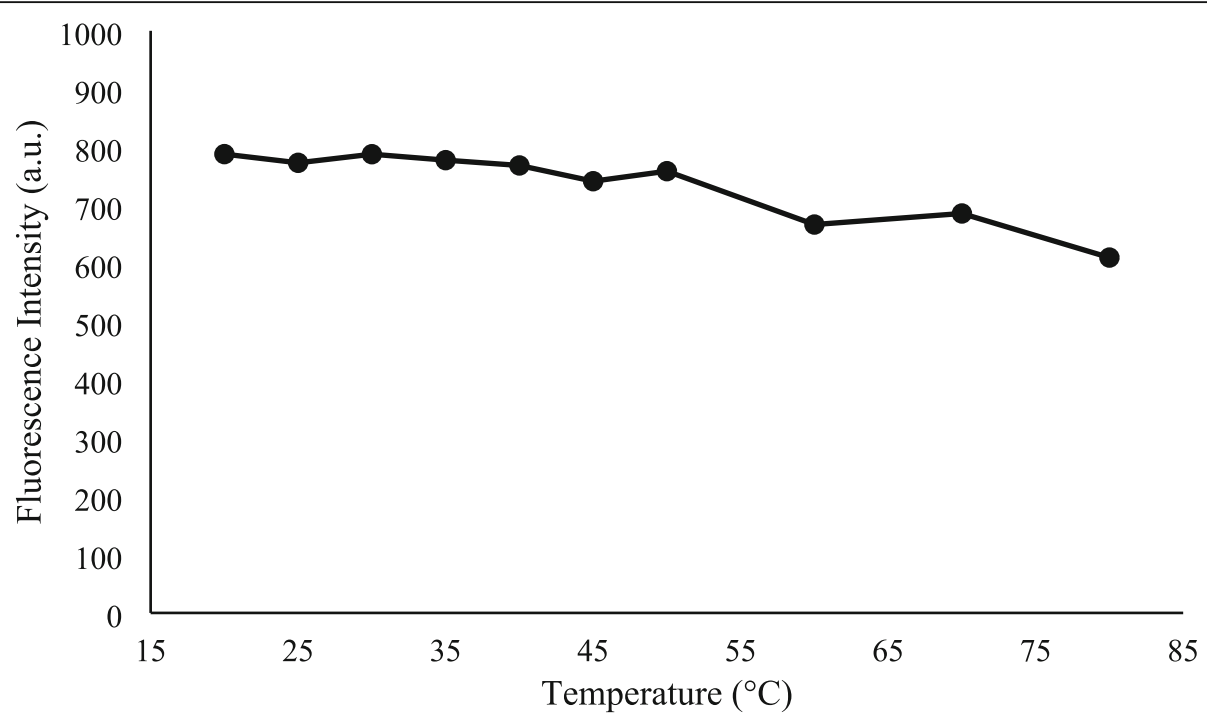

Fig. 7 Effect of temperature on native fluorescence intensity

parameters. Stationary and mobile phase systems and different internal standards used for the optimization of the HPLC method are summarized in Table 1. DAD detector was set at 250.0, 254.0, 260.0, 265.0, and $270.0 \mathrm{~nm}$ for all conditions.

Best separation and system performance was achieved on a Wakosil-II $5 \mathrm{C}_{18} \mathrm{AR}, 4.6 \times 250 \mathrm{~mm}$ analytical column using acetonitrile: $0.5 \%$ formic acid (99.5:0.5; v/v) as mobile phase. The best resolution is obtained tenofovir and ritonavir. Flow rate was 1.0 $\mathrm{mL} / \mathrm{min}$. Injection volume was $5.0 \mu \mathrm{L}$. Analytical data of $260.0 \mathrm{~nm}$ was used for the analysis. System performance data is summarized in Table 2.

\section{Validation parameters}

Purposed methods were validated for their linearity, accuracy, and precision according to ICH guidelines [35].

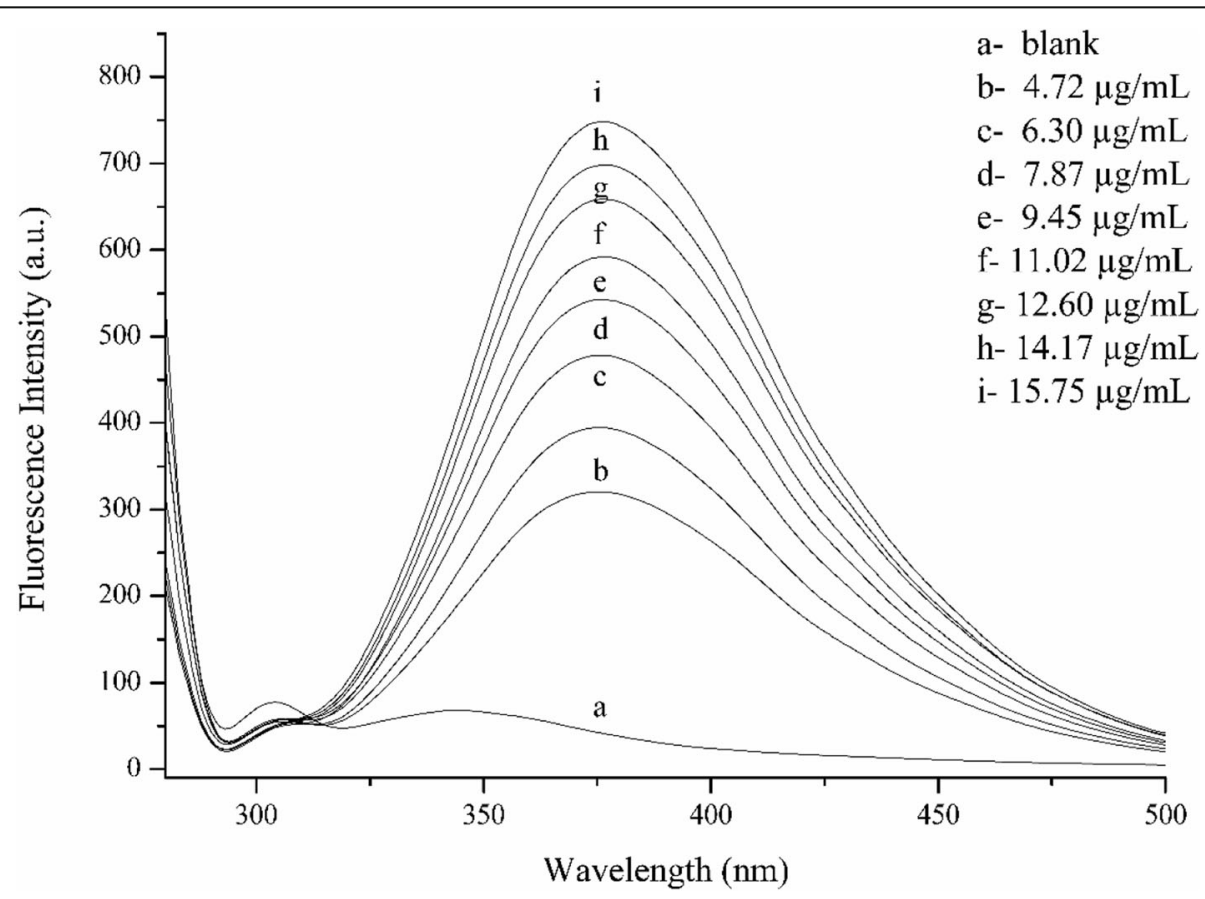

Fig. 8 UV-spectrums of the tenofovir calibration solutions 


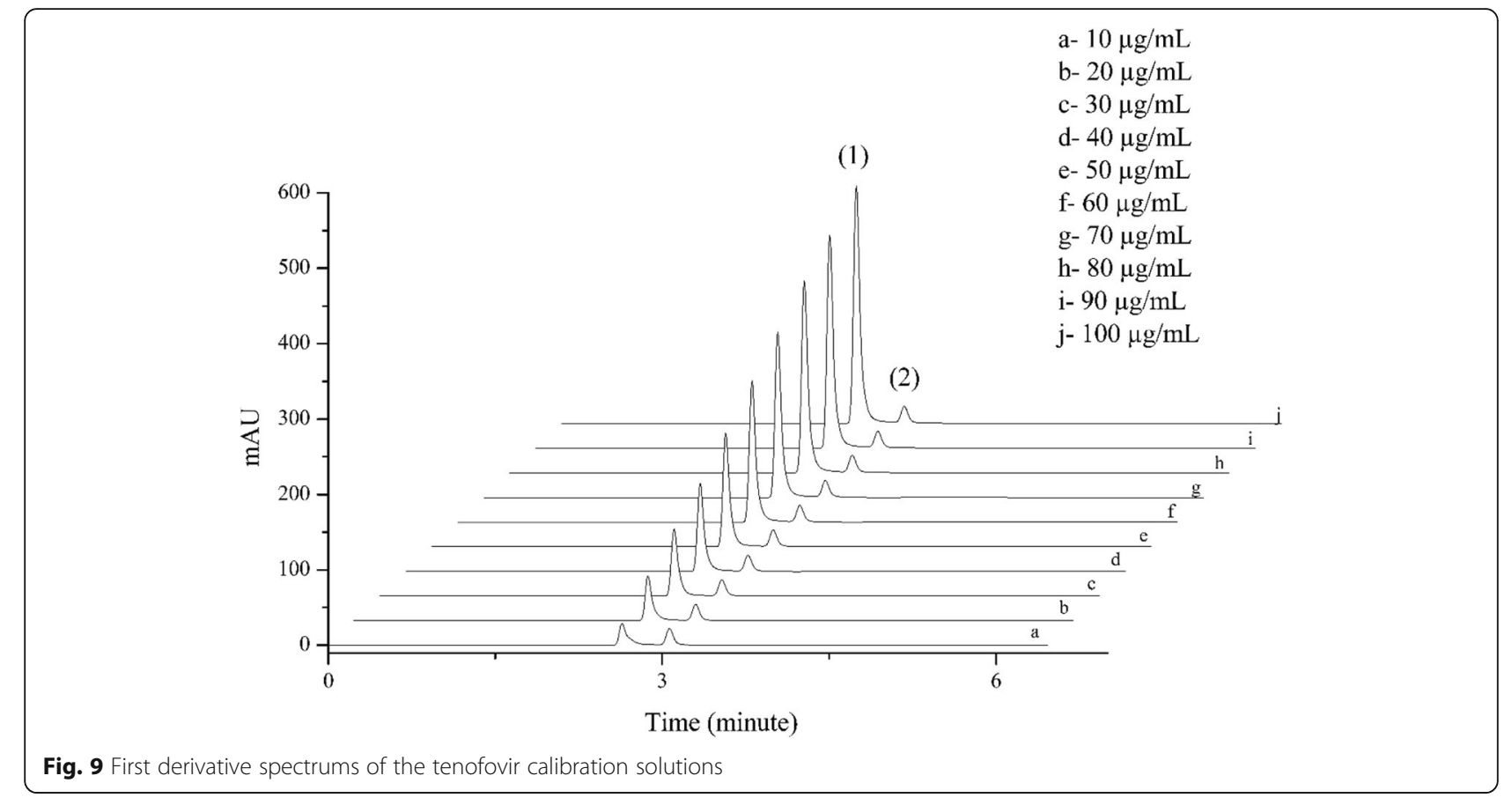

\section{Linearity}

Appropriate volumes of TDF stock solution were transferred to $10.0-\mathrm{mL}$ volumetric flasks; $1.0 \mathrm{~mL}$ of $\mathrm{pH} 2.26$ buffer and 2.0\% SDS solutions were added and completed to the volume with distilled water. Tenofovir concentration was between 4.72 and $15.75 \mu \mathrm{g} / \mathrm{mL}$ range for the spectrofluorimetric method (Method I). Spectrums of these solutions are shown in Fig. 10. Regression line was calculated by the least squares method [35]. Coefficient of determination $\left(r^{2}\right)$ was found to be 0.9994 which indicates good linearity.

In the first derivative spectrophotometric method (Method II), Beer's law range, linear regression equations, and correlation coefficients determined for each method are given in Table 3.

For HPLC method (Method III), appropriate dilutions were made from the stock solutions of ritonavir and TDF. Tenofovir concentrations were between 10.0 and $100.0 \mu \mathrm{g} / \mathrm{mL}$, and the ritonavir concentration was $125.4 \mu \mathrm{g} / \mathrm{mL}$ in each solution. Calibration graph was plotted via least square method $\left(r^{2}=0.9990\right)$ [35]. Chromatograms of these solutions are shown in Fig. 11. Calculations were made by the formula below for the HPLC method.

$$
\text { Relative tenofovir peak area }=\frac{\text { Tenofovir peak area }}{\text { Ritonavir peak area }}
$$

For Method I, eight sets of solutions were prepared as three series. For Method III, ten sets of solutions were prepared in three series and 3 injections were made for each serial of each concentration. Statistical data of the calibration graphs of the proposed methods are shown in Table 3. Limit of detection (LOD) and limit of quantitation (LOQ) values were calculated as described at $\mathrm{ICH}$ guidelines by the formulas given below, where $S_{b}$ is the standard deviation of the intercept of the regression line and $a$ is the slope of the calibration curve [35].

Table 1 Column, mobile phase systems, and internal standards used for the optimization of the HPLC method

\begin{tabular}{lll}
\hline Column & Mobile phase* & Internal standard \\
\hline Thermo Hypersil Phenyl $250 \times 4.6 \mathrm{~mm} 5 \mu$ & ACN:MeOH & Caffeine \\
& ACN:MeOH:Diethylamine & Hydrochlorothiazide \\
& ACN:0.5\% Formic acid & Zanamivir \\
Waters Xterra RP8 $5 \mu 250 \times 4.6 \mathrm{~mm}$ & ACN:MeOH & Oseltamivir \\
Wakosil-II 5 C18 AR, $4.6 \times 250 \mathrm{~mm}$ & ACN:0.5\% Formic acid & Lopinavir \\
\hline
\end{tabular}


Table 2 System performance parameters obtained by HPLC for tenofovir

\begin{tabular}{|c|c|c|}
\hline Parameters & HPLC & Reference value $[36,37]$ \\
\hline Retention time, $t_{\mathrm{r}}$ & 2.64 & - \\
\hline Capacity factor, $K^{\prime}$ & 3.19 & $K^{\prime}>2.0$ \\
\hline Resolution, $R_{\mathrm{s}}$ & 3.806 & $R_{\mathrm{s}}>2.0$ \\
\hline Selectivity, a & 4.437 & $a>1.0$ \\
\hline Theoretical plates, $N$ (plates/column) & 11207 & $N>2000$ \\
\hline Tailing factor, $T$ & 1.191 & $T \leq 2.0$ \\
\hline $\operatorname{RSD}(\%)$ & 0.12 & $\mathrm{RSD} \leq 1 \%$ \\
\hline
\end{tabular}

$R S D(\%)$ relative standard deviation of six replicate injections' peak areas

$$
\mathrm{LOD}=3.3 S_{b} / a ; \mathrm{LOQ}=10 S_{\mathrm{b}} / \mathrm{a}
$$

\section{Accuracy and precision}

Accuracy of the purposed methods was investigated via standard addition method. Known amount of tenofovir was added to a known concentration of tablet formulation. Five solutions at different concentrations in three series were prepared for the recovery studies. The statistical data of the recovery studies of Methods I, II, and III are given in Table 4. The results given in Table 3 indicate good accuracy and show that there is no interference with tablet excipients that are commonly used in formulations.

Precision of the purposed methods was investigated via intra- and inter-day analysis by preparing working solutions from the stock solutions mentioned before at three different concentrations as three series and by analyzing these samples at different times and days for intra- and inter-day analysis, respectively. Samples were kept at room, dark, and refrigerator conditions for the inter-day analysis. For each condition, solutions at three different concentrations were prepared and analyzed.

For Method I, samples were analyzed through $5 \mathrm{~h}$ and 5 days' timeline for the intra- and inter-day analysis, respectively. Samples were analyzed for $7.5 \mathrm{~h}$ and 5 days for intra- and inter-day analysis, respectively, for Method III. The results of the intra- and inter-day analysis are given in Table 5.

\section{Assay}

Methods I, II, and III were successfully applied to the finished product Ternavir ${ }^{\circ}$ tablets. Results that were obtained are shown in Table 6.

$t$ and $f$ values were calculated by the formulas given below. As it is seen on Table 6, calculated $t$ and $f$ values are smaller than the theoretical table $t$ and $f$ values

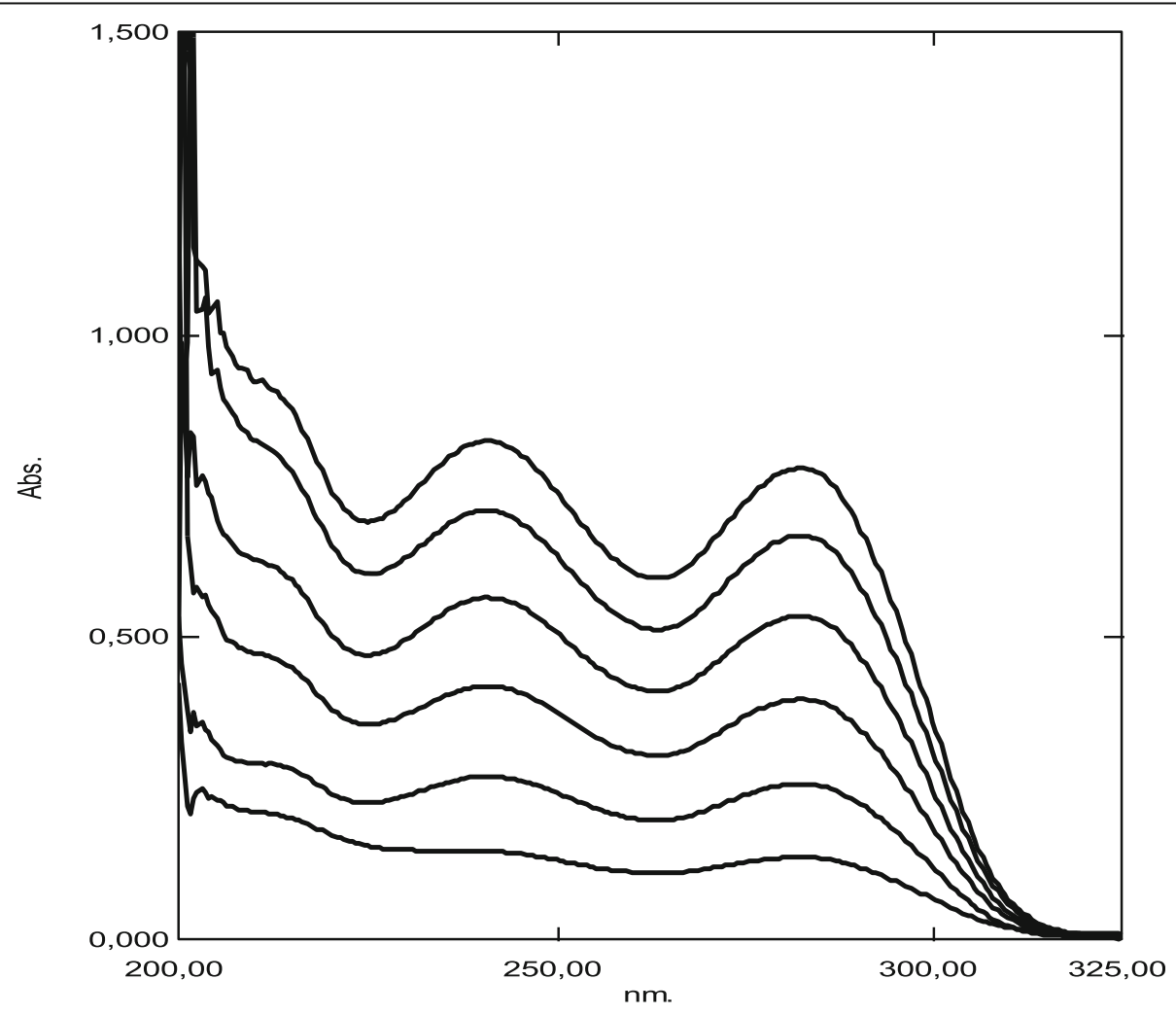

Fig. 10 Spectrums of the blank solution and the solutions containing increasing concentrations of tenofovir 
Table 3 Analytical parameters for the analysis of Tenofovir by the purposed spectrofluorimetric, first derivative spectrophotometric, and HPLC methods

\begin{tabular}{llll}
\hline Parameter & Method I & $\begin{array}{l}\text { Method } \\
\text { II }\end{array}$ & Method III \\
\hline Concentration range $(\mu \mathrm{g} / \mathrm{mL})$ & $\begin{array}{l}4.72- \\
15.75\end{array}$ & $\begin{array}{l}10.0- \\
\text { Slope }(a)\end{array}$ & $\begin{array}{l}10.00- \\
100.00\end{array}$ \\
Intercept $(b)$ & 39.002 & 0.9827 & 0.1398 \\
Correlation coefficient $(r)$ & 158.85 & 0.0073 & -0.0387 \\
Determination coefficient $\left(r^{2}\right)$ & 0.9997 & 0.9998 & 0.9995 \\
Standard deviation of the slope $\left(S_{a}\right)$ & 0.9994 & 0.9996 & 0.9990 \\
Standard deviation of the intercept & 17.85 & 1.00 & 0.0016 \\
$\left(S_{b}\right)$ & & & 0.0982 \\
Limit of detection $(\mathrm{LOD})(\mu \mathrm{g} / \mathrm{mL})$ & 1.51 & 1.31 & 2.32 \\
Limit of quantitation $(\mathrm{LOQ})(\mu \mathrm{g} / \mathrm{mL})$ & 4.58 & 4.53 & 7.02 \\
\hline
\end{tabular}

which are 2.78 and 6.39, respectively (for $n=5$ and $p=$ $0.05)$. This result indicates that there is no significant difference between the purposed methods' means and standard deviation values.

$$
f \text { value }=\left(\mathrm{SD}_{1}\right)^{2} /\left(\mathrm{SD}_{2}\right)^{2}
$$

where $\mathrm{SD}_{1}$ and $\mathrm{SD}_{2}$ are standard deviations of five quantitative determinations of Method I and Method II, respectively $\left(S D_{1}>S D_{2}\right)$.

$$
t \text { value }=\otimes C_{\text {mean }}-C_{\text {real }} \varangle /(\mathrm{SD} / \sqrt{ } n)
$$

where $C_{\text {mean }}$ is the mean of five determinations $(\mathrm{mg} /$ tablet), $C_{\text {real }}$ is the label value (135.58 $\mathrm{mg}$ tenofovir/tablet), SD is standard deviation of five determinations, and $n$ is the number of determinations $(n=5)$.

\section{Discussion}

In this study, spectofluorometric, chromatographic, and spectrophotometric methods were developed for determination of tenofovir disoproxil fumarate active substance in Ternavir ${ }^{\bullet}$ preparation.

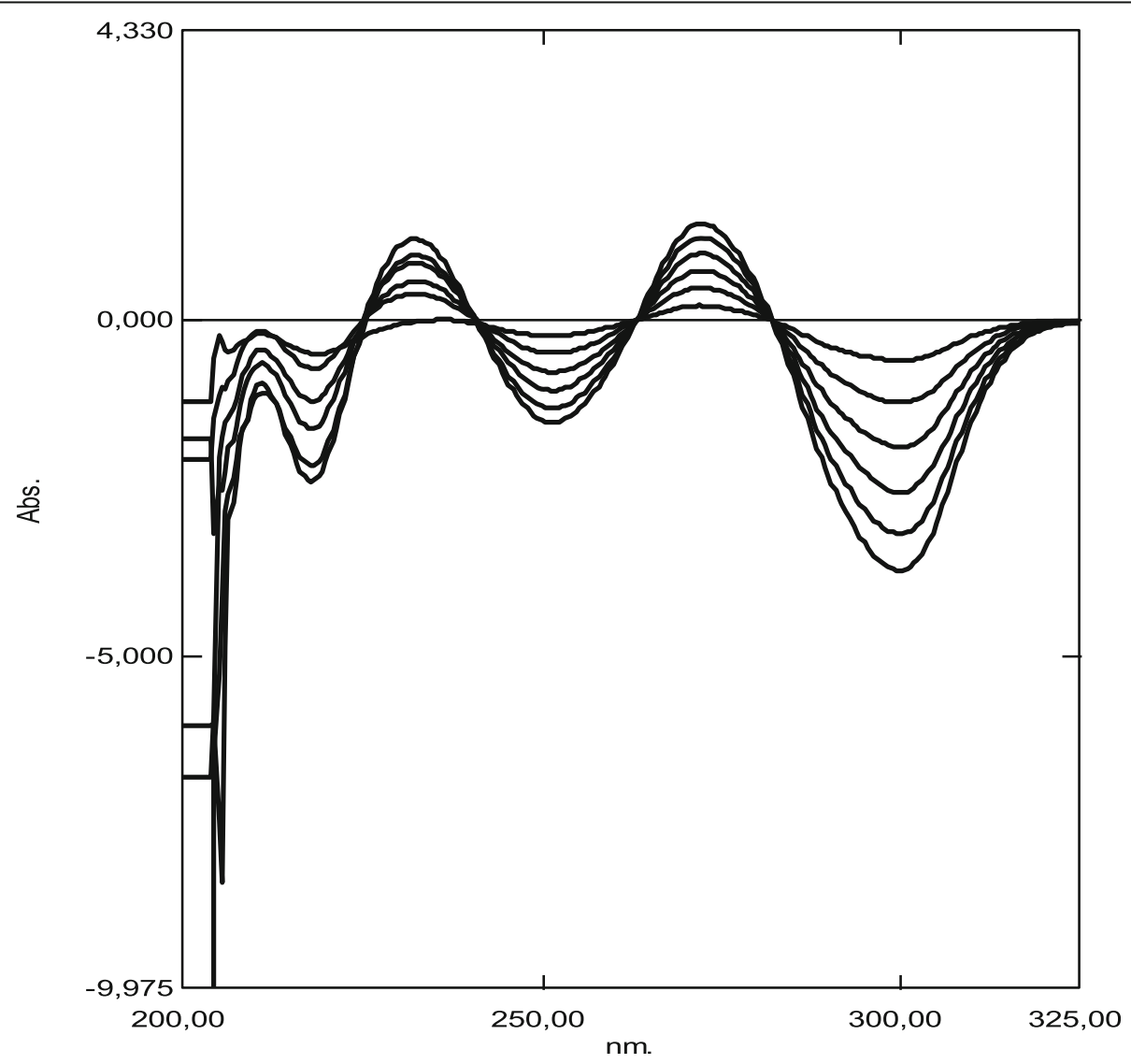

Fig. 11 Chromatograms of the tenofovir calibration solutions. (1) Tenofovir. (2) Ritonavir. Retention times of tenofovir and ritonavir are 2.64 and 3.07 min, respectively 
Table 4 Results of the recovery studies using standard addition method

\begin{tabular}{|c|c|c|c|c|c|c|c|c|c|c|c|c|c|c|}
\hline \multicolumn{5}{|l|}{ Method I } & \multicolumn{5}{|c|}{ Method II } & \multicolumn{5}{|c|}{ Method III } \\
\hline $\begin{array}{l}C_{\text {drug }} \\
(\mu \mathrm{g} / \mathrm{mL})\end{array}$ & $\begin{array}{l}C_{\text {add }} \\
(\mu \mathrm{g} / \\
\mathrm{mL})\end{array}$ & $\begin{array}{l}C_{\text {det }}^{*} \\
(\mu \mathrm{g} / \mathrm{mL})\end{array}$ & $\begin{array}{l}\text { \%Recovery } \\
\pm \mathrm{SD}\end{array}$ & $\% \mathrm{RSD}$ & $\begin{array}{l}C_{\text {drug }} \\
(\mu \mathrm{g} / \mathrm{mL})\end{array}$ & $\begin{array}{l}C_{\text {add }} \\
(\mu \mathrm{g} / \\
\mathrm{mL})\end{array}$ & $\begin{array}{l}C_{\text {det }}^{*} \\
(\mu \mathrm{g} / \mathrm{mL})\end{array}$ & $\begin{array}{l}\text { \%Recovery } \\
\pm \text { SD }\end{array}$ & $\%$ RSD & $\begin{array}{l}C_{\text {drug }} \\
(\mu \mathrm{g} / \mathrm{mL})\end{array}$ & $\begin{array}{l}C_{\text {add }} \\
(\mu \mathrm{g} / \\
\mathrm{mL})\end{array}$ & $\begin{array}{l}C_{\text {det }}^{*} \\
(\mu \mathrm{g} / \mathrm{mL})\end{array}$ & $\begin{array}{l}\text { \%Recovery } \\
\pm \mathrm{SD}\end{array}$ & \%RSD \\
\hline \multirow[t]{5}{*}{5.42} & 1.57 & 7.01 & $\begin{array}{l}101.31 \pm \\
2.74\end{array}$ & 2.70 & 12.00 & 2 & 14.02 & $\begin{array}{l}100.06 \pm \\
1.11\end{array}$ & 0.89 & 27.09 & 30 & 57.64 & $\begin{array}{l}101.85 \pm \\
0.71\end{array}$ & 0.70 \\
\hline & 3.18 & 8.64 & $\begin{array}{l}101.24 \pm \\
0.53\end{array}$ & 0.52 & & 4 & 15.96 & $\begin{array}{l}99.25 \pm \\
0.93\end{array}$ & 1.00 & & 40 & 65.16 & $\begin{array}{l}95.18 \pm \\
2.43\end{array}$ & 2.55 \\
\hline & 4.76 & 10.16 & $\begin{array}{l}99.61 \pm \\
0.73\end{array}$ & 0.74 & & 6 & 17.99 & $\begin{array}{l}97.82 \pm \\
1.08\end{array}$ & 0.99 & & 50 & 75.58 & $\begin{array}{l}96.98 \pm \\
1.38\end{array}$ & 1.42 \\
\hline & 6.30 & 11.98 & $\begin{array}{l}104.13 \pm \\
1.25\end{array}$ & 1.20 & & 8 & 20.10 & $\begin{array}{l}98.91 \pm \\
0.88\end{array}$ & 1.11 & & 60 & 85.10 & $\begin{array}{l}96.69 \pm \\
1.26\end{array}$ & 1.31 \\
\hline & 7.87 & 13.22 & $\begin{array}{l}99.04 \pm \\
2.25\end{array}$ & 2.27 & & 10 & 22.08 & $\begin{array}{l}99.04 \pm \\
0.99\end{array}$ & 1.26 & & 70 & 95.91 & $\begin{array}{l}98.32 \pm \\
1.39\end{array}$ & 1.41 \\
\hline
\end{tabular}

$C_{\text {drug }}$ drug concentration, $C_{\text {add }}$ added concentration, $C_{\text {det }}$ detected concentration, $S D$ standard deviation, $R S D$ relative standard deviation

* Mean concentration of three determinations

Various experiments have been conducted to optimize the spectrofluorimetric method. Dilutions were made with different solvents such as distilled water, methanol, and acetonitrile, and distilled water giving the highest fluorescence intensity was selected.

After the dilution solution was selected, buffer solutions with different $\mathrm{pH}$ values were prepared and the best solution was selected as $\mathrm{pH} 2.26$. In order to investigate the effect of the volume of the buffer solution, measurements were made by adding an increasing amount of buffer solution to the 10.0-ml flask. Since there was not much difference in fluorescence intensity and to use the buffer solution at least, it was decided to add $1.0 \mathrm{ml}$ of the buffer solution.

Different surfactants were tried to optimize the fluorescence intensity, and sodium dodecyl sulfate solution $(2.0 \%, \mathrm{w} / \mathrm{v})$ was selected. $1.0 \mathrm{ml}$ of sodium dodecyl sulphate solution was decided to be added, because the

Table 5 Precision data of tenofovir by proposed methods

\begin{tabular}{|c|c|c|c|c|c|c|c|}
\hline \multicolumn{4}{|l|}{ Method I } & \multicolumn{4}{|l|}{ Method III } \\
\hline$C_{\text {real }}(\mu \mathrm{g} / \mathrm{mL})$ & Conc.* Found $(\mu \mathrm{g} / \mathrm{mL})$ & $\%$ Recov. $^{* *} \pm S D$ & $\% \mathrm{RSD}$ & $C_{\text {real }}(\mu \mathrm{g} / \mathrm{mL})$ & Conc.* Found $(\mu \mathrm{g} / \mathrm{mL})$ & $\%$ Recov. $^{* *} \pm S D$ & $\%$ RSD \\
\hline & Intra-day analysis & & & & Intra-day analysis & & \\
\hline 6.26 & 6.43 & $102.64 \pm 3.17$ & 3.09 & 30.00 & 30.33 & $101.09 \pm 0.79$ & 0.79 \\
\hline 9.40 & 9.95 & $105.87 \pm 1.29$ & 1.22 & 50.00 & 48.64 & $97.28 \pm 0.50$ & 0.51 \\
\hline \multirow[t]{2}{*}{12.53} & 12.86 & $102.61 \pm 0.57$ & 0.56 & 70.00 & 68.82 & $98.31 \pm 0.74$ & 0.75 \\
\hline & Inter-day analysis & & & & Inter-day analysis & & \\
\hline Room & & & & Room & & & \\
\hline 6.26 & 6.28 & $100.38 \pm 0.81$ & 0.80 & 30.00 & 29.78 & $99.25 \pm 2.56$ & 2.58 \\
\hline 9.40 & 10.63 & $113.09 \pm 5.52$ & 4.88 & 50.00 & 48.13 & $96.27 \pm 1.80$ & 1.87 \\
\hline 12.53 & 13.72 & $109.52 \pm 5.14$ & 4.69 & 70.00 & 68.05 & $97.21 \pm 2.17$ & 2.23 \\
\hline Dark & & & & Dark & & & \\
\hline 6.26 & 7.02 & $112.15 \pm 6.61$ & 5.89 & 30.00 & 29.91 & $99.70 \pm 3.19$ & 3.20 \\
\hline 9.40 & 10.56 & $112.34 \pm 5.36$ & 4.77 & 50.00 & 49.29 & $98.58 \pm 2.03$ & 2.06 \\
\hline 12.53 & 13.68 & $109.21 \pm 4.59$ & 4.21 & 70.00 & 68.48 & $97.83 \pm 2.30$ & 2.36 \\
\hline Refrigerator & & & & Refrigerator & & & \\
\hline 6.26 & 6.73 & $107.53 \pm 2.37$ & 2.20 & 30.00 & 29.43 & $98.11 \pm 2.40$ & 2.45 \\
\hline 9.40 & 10.41 & $110.74 \pm 1.56$ & 1.41 & 50.00 & 48.56 & $97.12 \pm 1.23$ & 1.27 \\
\hline 12.53 & 13.39 & $106.85 \pm 1.58$ & 1.48 & 70.00 & 68.76 & $98.23 \pm 1.74$ & 1.78 \\
\hline
\end{tabular}

$C_{\text {real }}$ real concentration of the solution, Conc. concentration, Recov. recovery, SD standard deviation, $R S D$ relative standard deviation, $R E$ relative error 
Table 6 Statistical data obtained after application of the proposed methods to the tablet formulation

\begin{tabular}{|c|c|c|c|c|c|c|c|c|c|}
\hline \multirow[t]{2}{*}{ Dosage form } & \multicolumn{3}{|l|}{ Method I } & \multicolumn{3}{|l|}{ Method II } & \multicolumn{3}{|l|}{ Method III } \\
\hline & $\begin{array}{l}C_{\text {mean }} \pm S D(\mathrm{mg} / \\
\text { tablet })\end{array}$ & $\begin{array}{l}\% \\
\mathrm{RSD}\end{array}$ & C.I. & $\begin{array}{l}C_{\text {mean }} \pm S D(\mathrm{mg} / \\
\text { tablet) }\end{array}$ & $\begin{array}{l}\% \\
\mathrm{RSD}\end{array}$ & C.I. & $\begin{array}{l}C_{\text {mean }} \pm S D(m g / \\
\text { tablet })\end{array}$ & $\begin{array}{l}\% \\
\mathrm{RSD}\end{array}$ & C.I. \\
\hline $\begin{array}{l}\text { Ternavir }{ }^{\oplus} \text { tablet }(135.58 \mathrm{mg} \\
\text { Tenofovir/tablet) }\end{array}$ & $138.05 \pm 2.87$ & 2.08 & $\begin{array}{l}138.05 \pm \\
3.57\end{array}$ & $137.71 \pm 1.63$ & 1.04 & $\begin{array}{l}137.95 \pm \\
0.98\end{array}$ & $136.44 \pm 1.14$ & 0.84 & $\begin{array}{l}136.65 \pm \\
1.42\end{array}$ \\
\hline tcal & 1.93 & & & 2.13 & & & 1.68 & & \\
\hline fcal & 6.36 & & & & & & & & \\
\hline
\end{tabular}

amount added in different volumes did not change the fluorescence intensity.

The solutions prepared to examine the effect of temperature were kept in a water bath, and different temperatures were tested. As the spectrofluorimetric density decreased at $50.0{ }^{\circ} \mathrm{C}$, the experiments were decided to be carried out at room temperature.

HPLC and spectrophotometric methods were optimized. For HPLC experiments, the column and mobile phase were chosen which gave the best results and are shown in Table 1. In HPLC study, the system suitability parameters for tenofovir were found to be more sensitive compared to the studies in the literature and the analysis was completed faster [6].

Although the study with spectrofluorimetric detector is more sensitive in the literature, it is an expensive method. Our study is simple to be used in routine laboratories and its analysis time is short [8]. Our study is suitable for green chemistry compared to the studies in the literature $[15,30,32]$.

In order to prove the validity of the developed methods, the parameters reported in the sources were selected for the method validity tests and the relevant validity criteria were accepted [35]. For this purpose, validation studies' linearity, range, sensitivity, precision, recovery, repeatability, etc., parameters were investigated and statistical evaluations were made.

\section{Conclusion}

Spectrofluorimetric, first derivative spectrophotometric, and HPLC methods were developed for the determination of Tenofovir in pharmaceutical preparations. LOD and LOQ values indicate that both methods are sensitive. Correlation coefficients of the methods are close to 1.0 which supports the sensitivity. Intra- and inter-day analyses were performed, and the results that are obtained showed that the purposed methods are precise. Recovery studies point out good accuracy, and they indicate that there is no interference with the commonly used excipients in pharmaceutical preparations. Purposed methods were applied to the tablet formulation successfully. Proposed methods were also compared statistically via calculating $t$ and $f$ values, and no difference was found between methods. Proposed methods are rapid, simple, sensitive, accurate, and precise and can be used in many control laboratories for the determination of tenofovir in pharmaceutical preparations.

\section{Abbreviations}

HPLC: High-performance liquid chromatography; DAD: Diode array detector; UV: Ultraviolet; TDF: Tenofovir disoproxil fumarate; SDS: Sodium dodecyl sulfate; CTAB: Cetrimonium bromide; ACN: Acetonitrile; MeOH: Methanol; DMF: Dimethyl formamide; TLC: Thin layer chromatography; LC-MS/ MS: Liquid chromatography mass spectrometry/mass spectrometry; HPTL C: High-performance thin layer chromatography; ICH: International Council for Harmonization; SD: Standard deviation; RSD: Relative standard deviation; LOD: Limit of detection; LOQ: Limit of quantification

\section{Acknowledgements}

This research has been supported by Ankara University Scientific Research Projects Coordination Unit (Project Numbers: 19 L0237001; 19 L0237004)

\section{Authors' contributions}

NE designed and supervised the experiments, analyzed the data, and wrote the paper. EÇ performed the experiments. GT helped to draft the finally manuscript. All authors read and approved the final manuscript.

Funding

No funding was received.

Availability of data and materials

All data and materials are available upon request.

Ethics approval and consent to participate

Not applicable

Consent for publication

Not applicable

Competing interests

The authors declare that they have no competing interests.

\section{Author details}

${ }^{1}$ Department of Analytical Chemistry, Faculty of Pharmacy, Ankara University, Tandoğan, Ankara, Turkey. ${ }^{2}$ Department of Analytical Chemistry, Faculty of Pharmacy, Bezmialem Vakif University, Fatih, Istanbul, Turkey.

Received: 11 January 2020 Accepted: 6 August 2020

Published online: 04 September 2020

\section{References}

1. Craig CR, Stitzel RE (2004) Modern pharmacology with clinical applications, 6th edn. Lippincott Williams \& Wilkins, America, p 588

2. Zhou HY, Chen XH, Li W, Guan SY (2012) Mass analysis of tenofovir disoproxil fumarate and determination of fumarate combination ratio by NMR. Chinese Journal of Pharmaceutical Analysis 32(12):2180-2183 
3. Kalpana J, Himaja M, Anbarasu C (2015) Rapid stability indicating RP-HPLC method for simultaneous quantification of related impurities of antiretroviral drugs. Asian J Chem 27(7):2393-2395

4. Liu C, Zhong X, Xi Y, Tang Y, Jiang L, Wang F, Pu T, Zeng S (2015) Determination of the related substances of tenofovir by RP-HPLC. Journal of China Pharmaceutical University 46(1):78-80

5. Zhang Z, Wang L, Xu X, Dong Y, Zhang $L$ (2015) Development of a validated HPLC method for the determination of tenofovir disoproxil fumarate using a green enrichment process. Anal Methods 7(15):6290-6298

6. Abdel Hay MH, Gazy AA, Shaalan RA, Ashour HK (2015) Selective RP-HPLC DAD method for determination of tenofovir fumarate and emtricitabine in bulk powder and in tablets. Acta Chromatogr 27(1):41-54

7. Srinath A, Sneha B, Alladi A, Ahmed R, Kulkarni R (2014) Method development and validation for simultaneous estimation of lamivudine, tenofovir and efavirenz in combined tablet dosage form by RP-HPLC and UV-spectroscopic method. Int J Pharm Sci Res 5(12):5491-5497

8. Jullien V, Treluyer J, Pons G, Rey E (2003) Determination of Tenofovir in human plasma by high-performance liquid chromatography with spectrofluorimetric detection. J Chromatogr B Anal Technol Biomed Life Sci 785(2):377-381

9. Nirogi R, Bhyrapuneni G, Kandikere V, Mudigonda K, Komarneni P, Aleti R, Mukkanti K (2009) Simultaneous quantification of a non-nucleoside reverse transcriptase inhibitor efavirenz, a nucleoside reverse transcriptase inhibitor emtricitabine and a nucleotide reverse transcriptase inhibitor tenofovir in plasma by liquid chromatography positive ion electrospray tandem mass spectrometry. Biomed Chromatogr 23(4):371-381

10. Zheng JH, Guida LA, Rower C, Castillo-Mancilla J, Meditz A, Klein B, Kerr BJ, Langness J, Bushman L, Kiser J (2014) Quantitation of tenofovir and emtricitabine in dried blood spots (DBS) with HPLC-MS/MS. J Pharm Biomed Anal 88:144-151

11. Wang BL, Hu JP, Sheng L, Chen H, Li Y (2013) Pharmacokinetics of tenofovir in Beagle dogs after oral dosing of tenofovir disoproxil fumarate using HPLC-MS/MS analysis. Yaoxue Xuebao 48(3):390-394

12. Simiele M, Carcieri C, De Nicolo A, Ariaudo A, Sciandra M, Calcagno A, Bonora S, Di Perri G, D'avolio A (2015) A LC-MS method to quantify tenofovir urinary concentrations in treated patients. J Pharm Biomed Anal 114:8-11

13. Yamada E, Takagi R, Sudo K, Kato S (2015) Determination of abacavir, tenofovir, darunavir, and raltegravir in human plasma and saliva using liquid chromatography coupled with tandem mass spectrometry. J Pharm Biomed Anal 114:390-397

14. Himes SK, Scheidweiler KB, Tassiopoulos K, Kacanek D, Hazra R, Rich K, Huestis MA (2013) Development and validation of the first liquid chromatography-tandem mass spectrometry assay for simultaneous quantification of multiple antiretrovirals in meconium. Analytical Chemistry (Washington, DC, United States) 85(3):1896-1904

15. Paliwal N, Jain P, Dubey N, Sharma S, Khurana S, Kumar Paliwal S (2014) A liquid chromatography tandem mass spectrometry based regulatory compliant method for the determination of tenofovir in human serum. Drug Research (Stuttgart, Germany) 64(6):306-312

16. Patel A, Patel A, Makwana A (2015) Development and validation of an accurate and precise LC-MS/MS method for determination of tenofovir and emtricitabine in human plasma. International Journal of Pharmaceutical, Chemical and Biological Sciences 5(1):372-380

17. Koehn J, Ho RJY (2014) Novel liquid chromatography-tandem mass spectrometry method for simultaneous detection of anti-HIV drugs lopinavir, ritonavir, and tenofovir in plasma. Antimicrob Agents Chemothe 58(5):2675-2680

18. Shah SAB, Mullin $R$, Jones $G$, Shah I, Barker J, Petroczi AA, Naughton DP (2013) Simultaneous analysis of antiretroviral drugs abacavir and tenofovir in human hair by liquid chromatography-tandem mass spectrometry. J Pharm Biomed Anal 74:308-313

19. Madeesh SK, Ismail Y, Gunasekaran V (2012) Development and validation for simultaneous estimation of lamivudine, tenofovir and efavirenz by UPLC. International Journal of Pharmacy (Hyderabad, India) 2(3):656-660

20. Kavitha KY, Geetha G, Hariprasad R, Venkatnarayanan R, Kaviarasu M (2013) Development and validation of RP-UPLC analytical method for simultaneous estimation of emtricitabine, rilpivirine, tenofovir disoproxil fumarate and its pharmaceutical dosage forms. International Research Journal of Pharmacy 4(1):150-155

21. Tiwari P, Yadav R, Avinash K, Vaidya V, Sathe PA, Gangrade D (2010) Development and validation of UPLC method for emtricitabine, tenofovir and efavirenz in pharmaceutical preparation. Analytical Chemistry An Indian Journal 9(2):247-251

22. Djerada Z, Feliu C, Tournois C, Vautier D, Binet L, Robinet A, Marty H, Gozalo C, Lamiable D, Millart H (2013) Validation of a fast method for quantitative analysis of elvitegravir, raltegravir, maraviroc, etravirine, tenofovir, boceprevir and 10 other antiretroviral agents in human plasma samples with a new UPLC-MS/MS technology. J Pharm Biomed Anal 86:100-111

23. Reddy AVB, Jaafar J, Bin Aris A, Abdul Majid Z, Umar K, Talib J, Madhavi G (2015) Development and validation of a rapid ultra high performance liquid chromatography with tandem mass spectrometry method for the simultaneous determination of darunavir, ritonavir, and tenofovir in human plasma: Application to human pharmacokinetics. J Sep Sci 38(15):2580-2587

24. Kiran KK, Rao AS, Sankar DG (2017) New analytical method validation report and forced degradation studies for assay of elvitegravir, tenofovir, emtricitabine and cobicistat by RP-UPLC. Indo American Journal of Pharmaceutical Sciences 4(12):4662-4672

25. De Nicolo A, Simiele M, Pensi D, Boglione L, Allegra S, Di Perri G, D'avolio A (2015) UPLC-MS/MS method for the simultaneous quantification of anti-HBV nucleos(t)ides analogs: entecavir, lamivudine, telbivudine and tenofovir in plasma of HBV infected patients. J Pharm Biomed Anal 114:127-132

26. More SJ, Tanduiwadkar SS, Nikam AR, Rathore AS, Sathiyanarayanan L, Mahadik KR (2013) Separation and determination of lamivudine, tenofovir disoproxil fumarate and efavirenz in tablet dosage form by thin-layer chromatographic-densitometric method. Journal of Planar Chromatography--Modern TLC 26(1):78-85

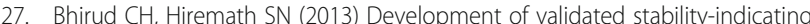
simultaneous estimation of Tenofovir disoproxil fumarate and emtricitabine in tablets by HPTLC. Journal of Pharmacy Research (Gurgaon, India) 7(2): 157-161

28. Pratima NA, Ajhar M, Shaikh O (2013) HPTLC method development, validation for simultaneous determination of efavirenz, emtricitabine and tenofovir in combined tablet formulation and forced degradation studies. American Journal of PharmTech Research 3(1):650-660

29. Nyamweru BC, Kaale E, Mugoyela V, Chambuso M (2013) Development and validation of an HPTLC-densitometric method for simultaneous analysis of lamivudine, tenofovir disoproxil fumarate, and efavirenz (LTE) in tablets. Journal of Planar Chromatography--Modern TLC 26(3):226-231

30. Susmitha K, Thirumalachary M, Charan Singh T, Venkateshwarlu G (2014) Extractive spectrophotometric determination of tenofovir disoproxil fumarate using acidic triphenylmethane dyes. ISRN Spectroscopy 856760/1856760/6, 7 pp.

31. Anees Ml, Baig MS (2015) Determination of lamivudine and tenofovir in pharmaceutical dosage form by simultaneous and Q-analysis UVspectrophotometric method. World Journal of Pharmacy and Pharmaceutical Sciences 4(3):688-696

32. Mondal N, Singh Y (2014) Development and validation of different spectrophotometric methods for estimation of tenofovir disoproxil fumarate from bulk drug and tablets. Int J Pharm Sci Res 5(2):623-629

33. Himaja M, Kalpana J, Anbarasu C (2014) Validated zero order and 1st order derivative spectrophotometric methods for in vitro analysis of tenofovir disoproxil fumarate tablets using azeotropic mixture. Int J Pharm Pharm Sci 6(6):302-304

34. Sunitha PG, Kaliappan I (2014) Validated first-order derivative spectrophotometry for simultaneous determination of emtricitabine and Tenofovir disoproxil fumarate in pharmaceutical dosage form. Journal of Drug Delivery and Therapeutics 4(2):9-11

35. International Conference on Harmonisation (ICH) (2005) Topic Q2 (R1): Validation of analytical procedures: text and methodology.

36. The United States Pharmacopoeia (USP 38) (2015) 621 Chromatography.

37. Center for Drug Evaluation and Research of the Food and Drug Administration (FDA) (1994) Reviewer Guidance Validation of Chromatographic Methods.

\section{Publisher's Note}

Springer Nature remains neutral with regard to jurisdictional claims in published maps and institutional affiliations. 